\title{
Strategy of Sports Brand Network Marketing on the Basis of Brand Image Promotion
}

\author{
Jiabin Zhang \\ Taishan univrisity, China. \\ 165665822@qq.com
}

\begin{abstract}
In order to enhance the brand influence and improve the brand image, Nike is taken as a case sample enterprise and its network marketing strategy practice is used as the research object. The application of case analysis, literature research and SWOT analysis is focused on to analyze the network marketing strategy of Nike. According to its shortcomings, corresponding optimization ideas are put forward, so as to provide reference for the network promotion and marketing of Nike and other domestic sporting goods brand. Network interaction can enhance the value of product brand and increase market share, and more effectively disseminate the brand image of enterprises. How enterprises make use of the property of network interaction to choose the correct strategy of brand image communication is related to whether the enterprise can stand out in the fierce market competition.
\end{abstract}

Keywords: Brand image, network interaction, network marketing.

\section{Introduction}

In recent years, the Internet has become the main channel for many brand merchants to promote brand image. In particular, the rise of social networks in recent years has made the big merchants set up their own brand communities, hoping their brand and consumers to achieve a benign interaction (Rui, Trail, Ross and Yoshida, 2017). However, there are few enterprises that can successfully use the Internet to promote brand image. In this era of information and digital, if the opportunity cannot be got on the network channel, it will be predominated by the competitors, so that the competitive brand is firmly positioned in the consumer psychology, so the later enterprise brand will be in a very passive state.

Some well-known enterprises at home and abroad have achieved good results in the promotion of network marketing. How do they use the network to promote the brand image? How do they adjust the center of focus among the various network media? The research and solution of these problems will help the Chinese brand wins the active marketing offensive in the network marketing era.

\section{State of the Art}

Foreign scholars have analyzed and studied the phenomenon of brand image transmission in the network channel, and deeply analyzed the theory of brand image network promotion and dissemination based on the actual operation steps, providing a very useful experience for domestic counterparts $(\mathrm{Li}, 2014)$. However, it is affected by the rapid development of network technology, and the research on network brand is at the beginning. Therefore, there will be a large number of rich and new research materials and new research ideas emerging in the research on Internet brand.

The research on the spread of Internet media in the brand image has just started in the domestic academic circles. At present, the research on this piece is still scattered and has not formed the systematic results. The domestic research is more about the application of technology to the actual operation level, it does not form a systematic operation scheme, and there is no certain theoretical depth (Dugalic and Ivic, 2015).

\section{Methodology}

How Nike establishes its own network marketing strategy, the specific implementation method of network marketing strategy, and the optimal allocation method of network media tools is mainly 
studied. The shortcomings of Nike's existing network marketing strategy are also pointed out, and a more perfect network marketing promotion model is summed up through theoretical and case analysis.

\subsection{Research Thought}

The theoretical basis is western economics, management and marketing. The research means is, through stating the existing model, to summarize and combine with theoretical analysis, and finally explore the comparatively innovative communication mode. Consulting literature and online research are used as the main research tools to analyze the current brand image promotion means and the current situation of network marketing promotion. In addition, some suggestions on how to use the network media to promote the brand image of the enterprise are put forward.

The feature is to use Nike as a typical case to analyze how sports goods brands use various kinds of new network media to form a network marketing plan to achieve successful brand image through network promotion. Finally, combining the related theories of network marketing and brand image promotion, the existing shortcomings and causes of Nike's current network marketing planning scheme are analyzed, and the corresponding improvement schemes are put forward.

\subsection{Research Method}

The following research methods are mainly adopted: literature research, case study and SWOT analysis.

Literature research: through reading a large number of research literature, including the fields of economics and management, the background, current situation, development model and development trend of network marketing are summarized and collocated.

Case study method: combining the actual market situation, taking the Nike case as the material, the detailed analysis and dissecting the complete process of the Nike brand network promotion promote people to enter the specific marketing situation and marketing process and establish the true feelings of the Nike network marketing strategy, and guide the readers to seek the optimization idea for solving the problem of enterprise network marketing practice.

SWOT analysis: the brand network marketing mode of China's sports industry is summarized, and the advantages, disadvantages, threats and opportunities of different modes of Nike marketing strategy are analyzed one by one. Moreover, the corresponding SWOT matrix is made, so as to make a comprehensive and all-round analysis of the marketing strategy practice of the Nike network. Finally, the specific ideas of Nike network marketing strategy optimization are obtained.

\subsection{Research Process}

The online marketing mode based on the main website plays a very important role in the brand sales of sports goods in China. The main website plays an essential role in the positive development of network marketing. The main website is a window used to centrally display all brand products. The main website is a central area used to contact all the online brands (Plewa, Carrillat, Mazodier and Quester, 2016). The main website is also a foundation and a cornerstone of the development of various other network marketing modes. The mode based on the main website is conducive to the management, coordination, feedback, contact and interaction with the consumer, because the main website is a website of a brand itself.

However, the online marketing mode based on the main website also has its disadvantages. For some famous sports goods brands, influenced by their brands, the main website often develops better and faster. But for some small and medium-sized sports goods brands or original brand established soon, the main website will often be submerged in the vast network world.

The promotion strategy of Nike's main website mode is successful. Nike.com used to provide information about Nike company, which is an information distribution website. Later, with the transformation of Nike's network promotion strategy, Nike began to focus on building the website Nike.com into a network sales channel rather than an information access channel (Tsordia, Papadimitriou and Parganas, 2018). The result is a sharp drop of $25 \%$ in web traffic. When the outside world has just expressed criticism and sympathy for Nike, the website's monthly average sales is 
increased by $5 \%$, the website's customer conversion rate is also increased by $67 \%$, and the number is still rising (Schade, Piehler and Burmann, 2014). The SWOT analysis table of Nike based on the main website mode is shown in Table 1.

Table 1. The SWOT analysis table of Nike based on the main website mode

\begin{tabular}{|c|c|}
\hline $\begin{array}{ll}\text { Strength }(\mathrm{S}) \\
\end{array}$ & Weakness \\
\hline $\begin{array}{l}\text { S1: the strength of the network resources is got together. The } \\
\text { ways of marketing are diversified, which is convenient for } \\
\text { management. } \\
\text { S2: it has an independent main website, which is conducive to } \\
\text { increasing the probability of Internet visitors being } \\
\text { transformed into buyers. }\end{array}$ & $\begin{array}{l}\text { W1: users are few and range is small, and it is } \\
\text { necessary to promote the main website } \\
\text { individually. } \\
\text { W2: the cost of promotion is high and the cost } \\
\text { of enterprise is increased. }\end{array}$ \\
\hline $\begin{array}{ll} & \text { Oppor } \\
\end{array}$ & \\
\hline $\begin{array}{l}\text { O1: excellent main website has great promotion function to } \\
\text { brand development. } \\
\text { O2: it can enhance the speed and efficiency of brand } \\
\text { communication among consumers. }\end{array}$ & $\begin{array}{l}\text { T1: the competition of the main website of the } \\
\text { same industry brand is fierce. } \\
\text { T2: the main website is difficult to operate. } \\
\text { T3: there is little difference between all kinds } \\
\text { of main websites. }\end{array}$ \\
\hline
\end{tabular}

SWOT analysis with the help of other website modes:

With the help of other websites, the mode of network marketing is very significant, that is, less input costs. Sports products brand can be put advertises on some famous websites, so it can save a lot of the cost of establishing and maintaining the website, but also can get better publicity effect.

However, the Internet marketing mode with the help of other websites also has its limitations. The main website represents an authoritative position of its own brand. After all, the network marketing dependent on other websites is based on other websites (Sierra and Taute, 2018). This success cannot do as the main site that can fully play the whole, the positive and the core role.

In addition, there are also some uncertainties in the Internet marketing mode of other websites. Due to a dependent marketing carrier rather than a part of the brand itself after all, although it has a certain impact force, the uncontrollable factors should be noted. Therefore, sports products brand should carefully choose the network platform to rely on; otherwise there will be some unforeseen threats. The SWOT analysis table that Nike uses other website mode is shown in Table 2:

Table 2. The SWOT analysis table that Nike uses other website mode

\begin{tabular}{|c|c|}
\hline Strength (S) & Weakness (W) \\
\hline $\begin{array}{c}\text { S1: it has high cost performance. } \\
\text { S2: can enhance the brand awareness by } \\
\text { using other websites. }\end{array}$ & $\begin{array}{c}\text { W1: it lacks product authority information publishing platform. } \\
\text { W2: marketing lacks the core carrier. }\end{array}$ \\
$\begin{array}{c}\text { S3: it has small investment but high } \\
\text { publicity effect. }\end{array}$ & $\begin{array}{c}\text { W3: it is difficult to establish consumer confidence in brand in } \\
\text { the process of network communication. }\end{array}$ \\
\hline $\begin{array}{c}\text { Opportunity (O) } \\
\text { O1: a new marketing carrier promotes the } \\
\text { development of this mode. }\end{array}$ & Threat (T) \\
\hline
\end{tabular}

Brand promotion has some similarities with TV advertising. Brand promotion is that the sporting goods brand publishes a variety of information about products on the website in order to win the favor of consumers. The strength of this mode is very clear, so this mode is more intuitive and traditional, in line with consumer psychology, but also easy to accept. In addition, the brand promotion mode has various forms and rich connotation.

However, the brand promotion mode also has its weakness. This mode does not actively utilize network or computer technology. After all, the current network marketing is a big trend. Because the network platform not only provides the space for the full display of the product, it is more worth mentioning that the way of shopping is greatly convenient, and online shopping provides convenience for sports goods brands and many consumers. The SWOT analysis table of Nike brand promotion mode is shown in Table 3. 
Table 3. The SWOT analysis table of Nike brand promotion mode

\begin{tabular}{|c|c|}
\hline Strength $(\mathrm{S})$ & Weakness (W) \\
\hline $\begin{array}{l}\text { S1: it is traditional and simple. } \\
\text { S2: it is easy to be accepted by the consumers. }\end{array}$ & $\begin{array}{l}\text { W1: the form is fixed. } \\
\text { W2: the convenience of network technology is not used. }\end{array}$ \\
\hline Opportunity $(\mathrm{O})$ & Threat (T) \\
\hline $\begin{array}{l}\text { O1: the number of netizens is expanding } \\
\text { continuously. } \\
\text { O2: there is a huge marketing group. }\end{array}$ & $\begin{array}{l}\text { T1: a single brand promotion model is gradually } \\
\text { eliminated. }\end{array}$ \\
\hline
\end{tabular}

It will be the extension of the brand promotion mode in the direction of sales, and will get a new mode of sales, that is, "brand promotion + online sales" mode, which combines brand promotion and online sales.

The characteristics of this model are obvious, that is, online sales are supported on the basis of brand promotion. It is found that this mode can make full use of advanced network and computer technology, which is the advantage of the "brand promotion + online sales" mode. This mode is in line with the development of the network marketing trend, because with the promotion and development of the network computer, more and more netizens choose to shop on the Internet, and the market share of network marketing is also expanding. At the same time, network sales can eliminate the limitations of time and space and greatly save the cost, convenient for consumer's shopping.

However, the disadvantage of "brand promotion + online sales" mode should also be noted. In many commodities, sports products are not very suitable for the way of network sales because sporting goods are not standardized products. For instance, for books and electronic parts, there is not a big gap between products (Kang, Bennett and Peachey, 2016). However, the nature and price of sports products are quite different, and consumers will be more demanding when choosing. Network marketing is to promote certain sports products by publishing pictures and texts on the Internet. But these propaganda and introduction cannot fully meet the needs of consumers, nor fully reflect the quality and performance of the product, which give sales an unavoidable disadvantage. The SWOT analysis table of Nike's "brand promotion + online sales" mode is shown in Table 4.

Table 4. Nike's SWOT analysis table of "brand promotion + online sales" model

\begin{tabular}{|c|c|}
\hline Strength (S) & Weakness (W) \\
\hline $\begin{array}{c}\text { S1: consumer can directly shop online. } \\
\text { S2: the brand cost is reduced. }\end{array}$ & $\begin{array}{c}\text { W1: products are not suitable for online sales. } \\
\text { W2: consumer identity is low. }\end{array}$ \\
\hline Opportunity (O) & Threat (T) \\
\hline $\begin{array}{c}\text { O1: it keeps in step with the development trend of the } \\
\text { future network marketing. }\end{array}$ & T1: network security measures. \\
O2: it has the potential for development. & \\
\hline
\end{tabular}

All in all, the above four network marketing modes have their advantages and disadvantages, facing their own development opportunities, but there are unstable factors. Nike's marketing mode is a composite mode, that is, "marketing based on the main website + dependence on other websites" and "brand promotion + online sales". This complex mode can avoid the defects brought by a certain mode, actively play the advantages of different modes, attract more consumers, and thus play the role of network marketing to the extreme.

\section{Results and Discussion}

In view of the existing deficiencies of Nike in the network marketing strategy mentioned above, the following three optimization ideas are put forward:

\subsection{Internet Praise Management - Network Public Relations Communication}

Enterprises should provide consumers with a platform for discussion, which is conducive for enterprises to further tracking and studying consumer discussions and ideas. To communicate more 
easily with consumers, enterprises must understand the local culture and language environment, as well as some online language.

Public relations are the communication behaviors to coordinate the public relations and establish a good image. Brand communication should take the use of public relations as a basic means to achieve following the basic principles of public relations. Brand public relations communication can be disseminated through the relevant characteristics of the network. First of all, brand public relations communication can directly convey relevant information to the target audience and bypass some intermediate media. Companies that have e-mail addresses of customers or potential customers can send messages directly to customers instead of relying on traditional media. Secondly, the brand's network public relations communication must provide customers with the information they need, at least not make them uncomfortable. For example, introducing the innovative products and leading the trend of fashion can enable the customer make the right choice. Thirdly, due to the friendly interaction between users on the network, the enterprise can use this interactive technology to spread the network public relations of the brand. At the same time, it can strengthen the good private relations and emotional links between the enterprise and the relationship group and the news media.

\subsection{Establishment of a Valuable Customer Relationship}

Although online brand communication is more transparent and real-time, the purpose of online and offline brand communication is the same. It is found that this characteristic is becoming more and more obvious with the gradual understanding of the connotation of brand. The core of brand communication is to establish a valuable relationship with all stakeholders. The one-way transmission is a traditional marketing method and brand publicity means, that is, the consumer's persuasion and publicity are mainly conducted after the production of the products. From the development of brand connotation, it is seen that the purpose of brand communication since twenty-first Century is to create a valuable relationship with customers (and employees), which is far more than communication. The Internet has an interactive feature that gives the subject of brand communication an opportunity to have a real conversation with the customers. Through the instant network, the subjects of marketing communication can investigate the consumer, get the feedback from the consumer, deal with the crisis in time, and give thanks to the consumers who are loyal to the brand.

\subsection{Cooperation with Entertainment Media Platform}

The Internet plays an important role in such an era of entertainment, providing a wide variety of entertainment platforms (games, music, movies, chatting tools, etc.). A large number of netizens are gathered on these entertainment platforms, and many netizens are also entirely dependent on these entertainment tools. These netizens who like the entertainments are some of the young consumer groups, and are the target customers of Nike. Nike can cooperate with these entertainment tools, influence users through a certain form, communicate deeply with those who rely on the entertainment tools, and enhance the reputation and recognition of the brand.

\section{Conclusion}

The information dissemination mode of the network is unique and innovative, and it is a new interactive platform between media and business. Network interaction can enhance the value of product brand, increase market share, and more effectively disseminate the brand image of enterprises. How enterprises make use of the property of network interaction to choose the correct strategy of brand image communication is related to whether the enterprise can stand out in the fierce market competition.

As the world's largest sporting goods brand, Nike has been using the Internet to promote its brand image since 2006. Nike is neither a manufacturer nor a supplier. In essence, Nike should be a brand new owner. Nike, based on the marketing strategy based on the main website and dependent on other websites, puts the focus of brand image promotion on network marketing media such as Facebook, Twitter, Nike, UGC video website and other network marketing media, and achieves remarkable 
success. But its current network marketing strategy still has shortcomings: it ignores the cooperation with entertainment media platform, lacks Internet praise management, and lacks valuable customers. In view of the shortcomings of Nike in the network marketing strategy, the following three points of thought are put forward: network praise management - network public relations communication, establishment of valuable customer relations, and cooperation with the entertainment media platform.

\section{Acknowledgements}

This project was one part of program in "AHP comprehensive evaluation model and empirical research of sports product brand extension" and it was supported by the Shandong university humanities and social sciences research program.

\section{References}

[1]. Rui, B., Trail, G., Ross, S., \& Yoshida, M. (2017). A model bridging team brand experience and sponsorship brand experience. International Journal of Sports Marketing \& Sponsorship, 18(4), 380-399. doi.org/10.1108/ijsms-07-2016-0038.

[2]. Li, J. (2014). Application of marketing network in leisure sports industry. Advanced Materials Research, 926-930, 3758-3761. doi.org/10.4028/www.scientific.net/amr.926-930.3758.

[3]. Dugalic, S., \& Ivic, J. (2015). The sport celebrity endorsement in promotion of products and services, 46(3), 207-216. doi.org/10.5937/markt1503207d.

[4]. Plewa, C., Carrillat, F. A., Mazodier, M., \& Quester, P. G. (2016). Which sport sponsorships most impact sponsor csr image?. European Journal of Marketing, 50(5/6), 796-815. doi.org/10.1108/ejm-02-2015-0078.

[5]. Tsordia, C., Papadimitriou, D., \& Parganas, P. (2018). The influence of sport sponsorship on brand equity and purchase behavior. Journal of Strategic Marketing, 26(1), 85-105. doi.org/10.1080/0965254x.2017.1374299.

[6]. Schade, M., Piehler, R., \& Burmann, C. (2014). Sport club brand personality scale (scbps): a new brand personality scale for sport clubs. Journal of Brand Management, 21(7-8), 650-663. doi.org/10.1057/bm.2014.36.

[7]. Sierra, J. J., \& Taute, H. A. (2018). Brand tribalism in technology and sport: determinants and outcomes. Journal of Brand Management, 1-17. doi.org/10.1057/s41262-018-0121-5.

[8]. Kang, C., Bennett, G., \& Peachey, J. W. (2016). Five dimensions of brand personality traits in sport. Sport Management Review, 19(4), 441-453. doi.org/10.1016/j.smr.2016.01.004. 